\title{
Trace elements in type 2 diabetes mellitus and their association with glycemic control
}

\author{
Rana MW Hasanato
}

Department of Pathology, College of Medicine and University Hospitals, King Saud University, Riyadh, Kingdom of Saudi Arabia.

\begin{abstract}
:
Background: Alterations in serum levels of trace elements reported in type 2 diabetes mellitus (T2DM) have been linked with induction of T2DM and associated complications.

Objectives: To assess serum levels of copper $(\mathrm{Cu})$, zinc $(\mathrm{Zn})$ and selenium $(\mathrm{Se})$ in T2DM patients with adequate and poor glycemic control.

Patients and methods: This study was performed at King Khalid University Hospital, Riyadh. A total of 100 consenting T2DM patients comprising of 50 patients with glycated hemoglobin (HbA1c) less than $6.5 \%$ and 50 patients with HbA1c more than 6.5\% along with a group of 50 normal healthy individuals were included in the study. Serum levels of $\mathrm{Cu}, \mathrm{Zn}$ and $\mathrm{Se}$ were measured by inductively coupled plasma-mass spectrometry (ICP-MS) instrument.

Results: Among T2DM patients with $\mathrm{HbA1c}<6.5 \%$, mean serum $\mathrm{Cu}$ levels $(13.4+4.3 \mu \mathrm{mol} / \mathrm{L})$ were not different from the controls $(14.5+1.92 \mu \mathrm{mol} / \mathrm{L})$ whereas $\mathrm{Zn}(9.9+2.7 \mu \mathrm{mol} / \mathrm{Lvs} 15+3.2 \mu \mathrm{mol} / \mathrm{L} ; \mathrm{p}<0.0001)$ and Se levels $(1+0.2 \mu \mathrm{mol} /$ Lvs1.62+0.2 $\mathrm{mol} / \mathrm{L} ; \mathrm{p}<0.0004)$ were lower than the controls. Among T2DM patients with $\mathrm{HbA} 1 \mathrm{c}>6.5 \%$ mean serum $\mathrm{Cu}$ $(18.1+4.1 \mu \mathrm{mol} / \mathrm{Lvs} 14.5+1.9 \mu \mathrm{mol} / \mathrm{L} ; \mathrm{p}<0.0001), \mathrm{Zn}(15+3.2 \mu \mathrm{mol} / \mathrm{Lvs} 13.5+1.9 \mu \mathrm{mol} / \mathrm{L} ; \mathrm{p}<0.009)$ and Se $(1.62+0.2 \mu \mathrm{mol} /$ Lvs $1.17+0.16 \mu \mathrm{mol} / \mathrm{L} ; \mathrm{p}<0.0001)$ were significantly higher than the controls. HbA1c $\%$ negatively correlated with $\mathrm{HbA} 1 \mathrm{c}>6.5 \%$ $(\mathrm{r}=-0.302 ; \mathrm{p}<0.03)$.
\end{abstract}

Conclusion: $\mathrm{Cu}, \mathrm{Zn}$ and $\mathrm{Se}$ homeostasis was altered in T2DM patients and varied with glycemic control.

Keywords: Copper, Zinc, Selenium, trace elements, diabetes mellitus.

DOI: https://dx.doi.org/10.4314/ahs.v20i1.34

Cite as: Hasanato RMW. Trace elements in type 2 diabetes mellitus and their association with glycemic control. Afri Health Sci. 2020;20(1):28793. bttps://dx.doi.org/10.4314/ahs.v20i1.34

\section{Introduction}

Type 2 diabetes mellitus (T2DM) is a metabolic disorder characterized by impaired insulin secretion and altered glucose metabolism resulting in hyperglycemia. ${ }^{1}$ Trace elements including zinc $(\mathrm{Zn})$, copper $(\mathrm{Cu})$ and selenium (Se) are involved in several physiological functions at cellular level ${ }^{2}$ including functions related to insulin and glucose metabolism. ${ }^{3}$ Altered body composition of these micro-nutrients have been implicated in the development of T2DM. ${ }^{4}$ Hyperglycemia in diabetes on the other hand

\section{Corresponding author: \\ Rana MW Hasanato, \\ Department of Pathology, \\ College of Medicine and University Hospitals, \\ King Saud University, Riyadh, \\ Kingdom of Saudi Arabia. \\ Phone: 011-4679093 \\ Fax: 011-4672575 \\ E-mail: ranamomen@yahoo.com}

has been blamed for alterations in serum levels of these trace elements ${ }^{5}$ resulting in enhancement of oxidative stress and decreased production of insulin. ${ }^{6}$

$\mathrm{Zn}$ as an anti-oxidant trace element not only potentiates the actions of insulin ${ }^{7}$ but is also crucial for the production of insulin. ${ }^{8} \mathrm{Zn}$ deficiency reported in T2DM is believed to be due to increased urinary losses of this trace element and the reduced $\mathrm{Zn}$ status exhibits a negative correlation with hyperglycemia and poor glycemic control. ${ }^{9}$ Elevated levels of $\mathrm{Cu}^{10}$ a pro-oxidant trace element, are not only implicated in increased oxidative stress in T2DM but also contribute to insulin resistance and hyperglycemia. ${ }^{11}$ Despite these observations data regarding serum levels of $\mathrm{Zn}$ and $\mathrm{Cu}$ in T2DM are inconsistent with claims that $\mathrm{Zn}$ and $\mathrm{Cu}$ concentrations are not altered in T2DM. ${ }^{12}$ Moreover, Zn supplementation has been shown to exhibit a negative correlation of with glycated hemoglobin (HbA1c). ${ }^{13}$ Similarly, Se is considered as an anti-oxidant trace element and higher Se concentrations have been associated with

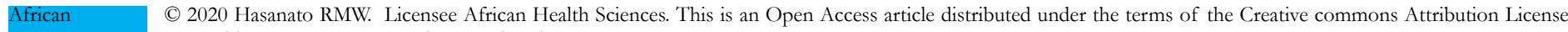

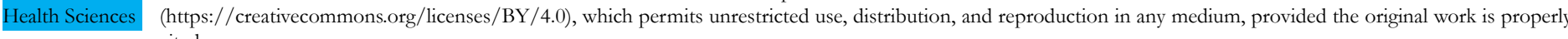
cited.
} 
decrease prevalence of T2DM. ${ }^{14}$ On the contrary there is evidence that higher serum Se concentration is associated with higher prevalence of T2DM, higher fasting plasma glucose and HbA1c percentage in T2DM. ${ }^{15}$

In the backdrop of conflicting data for trace elements in T2DM, this study was performed to assess the levels of $\mathrm{Zn}, \mathrm{Cu}$ and Se among patients with T2MD and to investigate whether the levels of trace elements in T2DM are associated with glycemic control.

\section{Patients and methods}

This study was performed in the Clinical Chemistry Unit at King Khalid University Hospital, Riyadh between June 2015 and September 2016. A total of 100 consenting patients both males and females with T2DM and 50 normal healthy controls were included in the study. T2DM patients were grouped on the basis of HbA1c $>6.5 \%$ (50 patients) and $\mathrm{HbA} 1 \mathrm{c}<6.5 \%$ (50 patients) into two groups with poor and optimal glycemic control respectively. Apart from the demographic details data regarding the duration of illness, current treatment for T2DM, vitamin and mineral intake and smoking status were also recorded. Inclusion criteria for patients were confirmed diagnosis of T2DM with positive glucose tolerance test, absence of coexisting acute or chronic illnesses other than T2DM associated complications and not receiving vitamin or mineral supplements at the time of inclusion in the study or at least three months before. Inclusion criteria for normal controls were absence of any acute or chronic illness and it was ensured that none of the controls was receiving oral supplements of vitamins or minerals at the time of collection of blood sample or at least three months before.

Table describes the characteristic features of the patients and controls. In the $\mathrm{HbA} 1 \mathrm{c}<6.5 \%$ group there were 31 females and 19 males with the mean age of $55.4+6.7$ years whereas in the HbA1c $>6.5 \%$ group comprised of 33 females and 17 males with the mean age of 57.8 +14.3 years. The control group had 28 females and 22 males with the mean age $50.2+10.3$ years. The mean $\mathrm{HbA} 1 \mathrm{c}$ of patients in group with $>6.5 \% \mathrm{HbA} 1 \mathrm{c}$ was
$10.4+1.1 \%$ whereas the mean $\mathrm{HbA} 1 \mathrm{c}$ of the patients in $<6.5 \%$ HbA1c group was $5.4+0.4 \%$. The duration of illness among T2DM patients with $>6.5 \% \mathrm{HbA} 1 \mathrm{c}$ was $10.4+4.7$ years and among patients with $\mathrm{HbA} 1 \mathrm{c}$ $<6.5 \%$ group was $8.7+5.1$ years. Whereas no diabetic complications were present in $<6.5 \%$ HbA1c group 13 $(26 \%)$ patients in group with $>6.5 \% \mathrm{HbA} 1 \mathrm{c}$ had microalbuminuria. Among the group of patients with $>6.5 \%$ HbA1c $27(54 \%)$ and in the group with $<6.5 \% \mathrm{HbA} 1 \mathrm{c}$ $17(34 \%)$ patients were receiving insulin whereas the rest of the patients were on oral hypoglycemic agents. None of the patients or the controls was either a current or ex-smoker. Serum levels of $\mathrm{Cu}, \mathrm{Zn}$ and Se were measured by inductively coupled plasma-mass spectrometry (ICP-MS) instrument (Perkin-Elmer). After obtaining the informed consent from each patient and control venous blood sample $(1 \mathrm{ml})$ was collected in royal blue tube using aseptic technique. Serum was separated after $30 \mathrm{~min}$ of clotting time and samples were kept frozen at $-80^{\circ} \mathrm{C}$ until analysis. A set of five-point calibration standards in $2 \%$ supra-pure nitric acid was used. Samples were diluted 1:50 in the same diluent as the corresponding calibration standards. The validity of the results obtained was checked by triple repetition of the analyses.

\section{Statistical analysis}

Data were analyzed by MedCalc computer software version 14.8.1. Categorical data were summarized as numbers and percentages. Numeric data were summarized as mean and standard deviation. Comparison between groups was performed using student $t$ test for independent samples and a $\mathrm{p}<0.05$ was considered statistically significant.

\section{Results}

Figure 1 compares data for serum levels of $\mathrm{Cu}, \mathrm{Zn}$ and Se of normal individuals and T2DM patients with $<6.5 \% \mathrm{HbA} 1 \mathrm{c}$. The mean serum copper levels among the T2DM patients $(13.4+4.3 \mu \mathrm{mol} / \mathrm{L})$ and the controls $(14.5+1.92 \mu \mathrm{mol} / \mathrm{L})$ were not different. The mean $\mathrm{Zn}$ level among the T2DM patients $(9.9+2.7 \mu \mathrm{mol} / \mathrm{L})$ was however significantly lower than the normal controls $(15+3.2 \mu \mathrm{mol} / \mathrm{L} ; \mathrm{p}<0.0001)$. Similarly, mean Se level among T2DM patients $(1+0.2 \mu \mathrm{mol} / \mathrm{L})$ was significantly lower than the controls $(1.62+0.2 \mu \mathrm{mol} / \mathrm{L} ; \mathrm{p}<0.0004)$. 


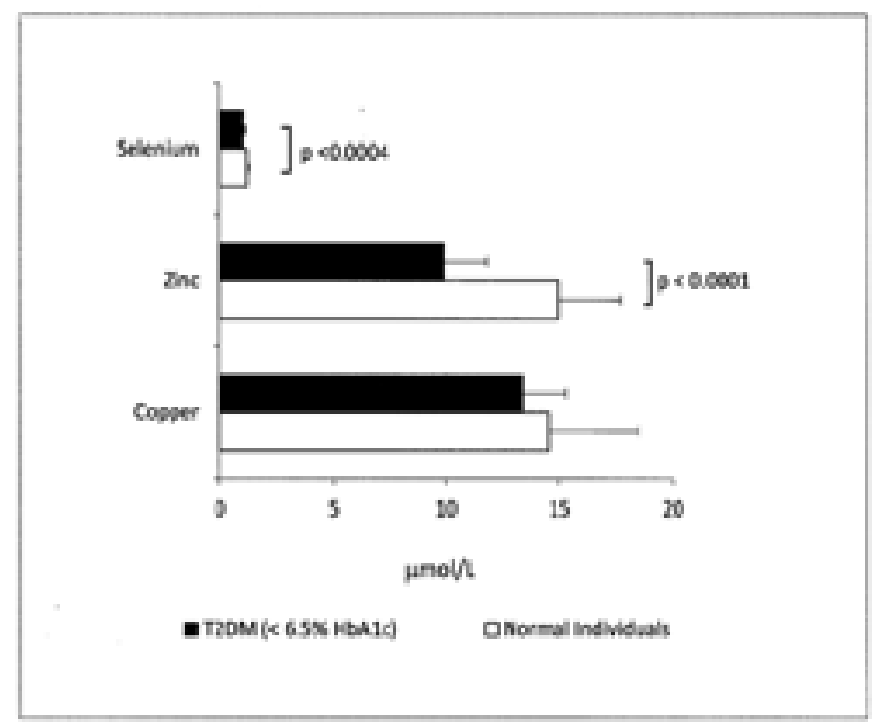

Figure. 1 Comparison of serum levels of trace elements among type 2 diabetes mellitus patients with glycated hemoglobin (HbA1c) of less than $6.5 \%$ with normal controls.

Figure 2 shows comparison of serum levels of $\mathrm{Zn}$, $\mathrm{Cu}$ and Se between the group of T2DM patients with $\mathrm{HbA} 1 \mathrm{c}>6.5 \%$ and normal healthy controls. Serum $\mathrm{Cu}$ level among T2DM patients $(18.1+4.1 \mu \mathrm{mol} / \mathrm{L})$ was significantly higher than the controls $(14.5+1.9 \mu \mathrm{mol} / \mathrm{L} ; \mathrm{p}$
$<0.0001)$. The mean $\mathrm{Zn}$ level $(15+3.2 \mu \mathrm{mol} / \mathrm{L})$ among the T2DM patients with $\mathrm{HbA} 1 \mathrm{c}>6.5 \%$ was also higher than the normal healthy individuals $(13.5+1.9 \mu \mathrm{mol} / \mathrm{L}$; $\mathrm{p}<0.009)$. Similarly, serum Se level of $1.62+0.2 \mu \mathrm{mol} / \mathrm{L}$ among T2DM patients was significantly higher than the normal controls $(1.17+0.16 \mu \mathrm{mol} / \mathrm{L} ; \mathrm{p}<0.0001)$.

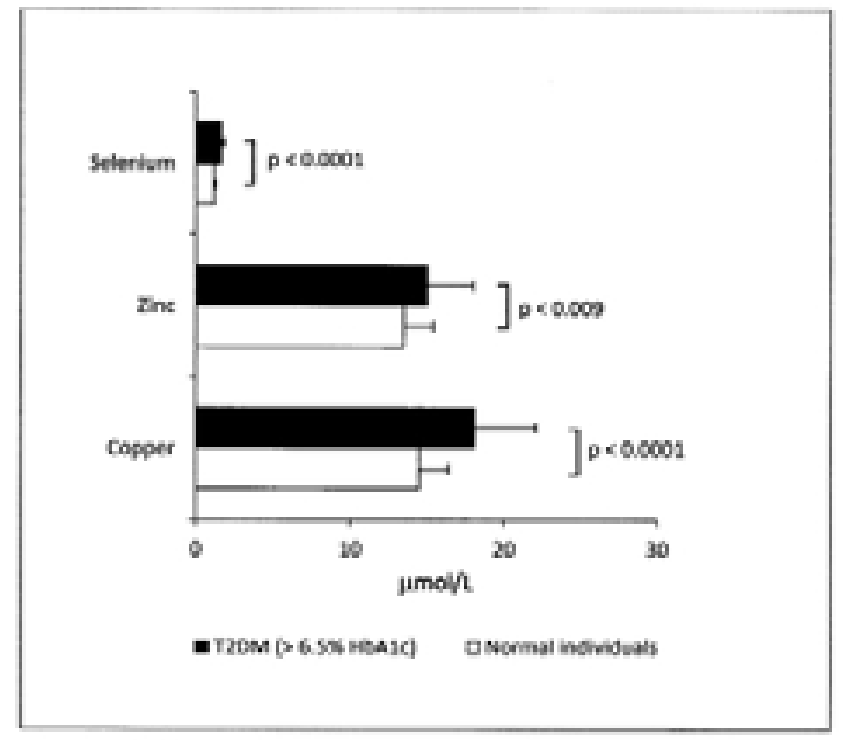

Figure. 2 Comparison of serum levels of trace elements among type 2 diabetes mellitus patients with glycated hemoglobin (HbA1c) of more than $6.5 \%$ with normal controls. 
Figure 3 shows data for comparison of serum $\mathrm{Cu}, \mathrm{Zn}$ and Se levels between T2DM patients with HbA1c of greater than and less than 6.5\%. The mean $\mathrm{Cu}, \mathrm{Zn}$ and Se levels among T2DM with HbA1c > 6.5\% were consistently higher than the group of patients with T2DM and
$\mathrm{HbA} 1 \mathrm{c}<6.5 \%(\mathrm{p}<0.0001)$. $\mathrm{Zn}$ and $\mathrm{Cu}$ ratio $(\mathrm{Zn} / \mathrm{Cu})$ among the normal individuals was 1.01, among T2DM patients with $\mathrm{HbA} 1 \mathrm{c}<6.5 \%$ was 1.7 and among T2DM patients with $\mathrm{HbA1c}>6.5$ was 0.76 . HbA1c percentage correlated negatively with $\mathrm{Zn} / \mathrm{Cu}$ only among patients with T2DM with HbA1c $>6.5 \%(r=-0.302 ; \mathrm{p}<0.03)$.

Figure. 3 Comparison of serum levels of trace elements among type 2 diabetes mellitus patients with glycated hemoglobin ( $\mathrm{HbA1c}$ ) of less than $6.5 \%$ and more than $6.5 \%$.

Table. Characteristic features of patients with type 2 diabetes mellitus and controls

\begin{tabular}{|c|c|c|c|}
\hline Variable & $\begin{array}{l}\text { HbA1c }<6.5 \% \\
\text { group } \\
n=50\end{array}$ & $\begin{array}{l}\text { HbA1c }>6.5 \% \\
\text { group } \\
n=50\end{array}$ & $\begin{array}{l}\text { Control } \\
\text { group } \\
n=50\end{array}$ \\
\hline Age \pm sd years & $55.4 \pm 6.7$ & $57.8 \pm 14.3$ & $50.2 \pm 10.3$ \\
\hline Males & 19 & 17 & 22 \\
\hline Females & 31 & 33 & 28 \\
\hline $\begin{array}{l}\text { Duration of illness } \pm \text { sd } \\
\text { years }\end{array}$ & $8.7 \pm 5.1$ & $10.4 \pm 4.7$ & - \\
\hline Mean $\mathrm{HbA} 1 \mathrm{c} \%$ & $5.4 \pm 0.4$ & $10.4 \pm 1.1$ & - \\
\hline Microalbuminuria $\mathrm{n}(\%)$ & - & $13(2 \overline{6} \%)$ & - \\
\hline Insulin treatment & $17(34 \%)$ & $27(54 \%)$ & - \\
\hline Smokers & - & - & - \\
\hline
\end{tabular}




\section{Discussion}

This study revealed that better glycemic control among T2DM patients was associated with low $\mathrm{Zn}$ and Se levels whereas poor glycemic control was associated with elevated levels of $\mathrm{Zn}, \mathrm{Cu}$ and Se compared to normal individuals. Low blood levels of $\mathrm{Zn}$ in T2DM patients observed in the present study are consistent with the previous findings that patients with T2DM tend to have hypozincemia along with the depletion of tissue zinc stores. ${ }^{16}$ Increased zincuria observed in diabetes is believed to be secondary to osmotic diuresis and diabetes related polyuria may also contribute to hypozincemia. ${ }^{17} \mathrm{Zn}$ deficiency has been associated with diabetic complications such as hypertension, thrombosis, ocular involvement, insulin production and resistance to insulin. ${ }^{7,18}$ The main reason for the wide ranging effects of $\mathrm{Zn}$ deficiency particularly in diabetes mellitus is due to $\mathrm{Zn}$ being a co-factor for over three hundred enzymes involved in various metabolic pathways. ${ }^{19}$ Improvement in a number of metabolic parameters following $\mathrm{Zn}$ supplementation in T2DM points to the importance of this trace element in pathogenesis of T2DM. ${ }^{20}$ Despite the existence of a body of evidence describing association of $\mathrm{Zn}$ with T2DM the exact role of $\mathrm{Zn}$ in the metabolic disorder remains unclear.

Serum levels of $\mathrm{Cu}$ were elevated among T2DM patients with poor glycemic control compared to normoglycemic T2DM patients and normal individuals. Increased $\mathrm{Cu}$ level among T2DM patients reported previously has been linked with the development of diabetes. ${ }^{21,22} \mathrm{Cu}$ is a pro-oxidant and high levels of $\mathrm{Cu}$ induce increased production hydrogen peroxide resulting in $\beta$ cell degeneration and development of $\mathrm{T} 2 \mathrm{DM}{ }^{23} \mathrm{Zn}$ on the other hand is bestowed with anti-oxidant and anti-inflammatory properties through its ability to down regulate the production of inflammatory cytokines. ${ }^{24}$ Deficient $\mathrm{Zn}$ levels and elevated $\mathrm{Cu}$ levels observed in diabetes mellitus therefore tilt the balance in favor of pro-inflammatory milieu. Elevated $\mathrm{Cu}$ levels along with reduced ceruloplasmin levels and decreased binding activity of $\mathrm{Cu}$ in diabetes leads to elevation of free $\mathrm{Cu}$ that is not only toxic but also promotes pro-oxidant activity. ${ }^{25}$ Hyperglycemia induces protein glycosylation and $\mathrm{Cu}$ exhibits increased affinity for these glycosylated proteins resulting in enhanced oxidative stress and production of free radicals predisposing T2DM patients to disease associated complications. $^{26}$

African Health Sciences Vol 20 Issue 1, March, 2020
The negative correlation of $\mathrm{Zn} / \mathrm{Cu}$ with $\mathrm{HbA} 1 \mathrm{c}$ observed in the present study among patients with poor glycemic controls was most likely due to significantly higher level of $\mathrm{Cu}$ contributing to reduction of $\mathrm{Zn} / \mathrm{Cu}$ most likely due to hyperglycemia induced increased free $\mathrm{Cu}$. Negative correlation between $\mathrm{HbA} 1 \mathrm{c}$ and $\mathrm{Zn} / \mathrm{Cu}$ has recently been reported among patients with T2DM. ${ }^{27}$ Association of high $\mathrm{Zn}$ and $\mathrm{Cu}$ level with high $\mathrm{HbA1c}$ has been reported where high $\mathrm{HbA1c}$ percentage tends to exhibit a positive correlation with $\mathrm{Cu}$ and a negative correlation with $\mathrm{Zn} .^{28}$ No such correlation was detected in the present study.

Serum Se level was lower among T2DM patients with good glycemic control than the normal individuals whereas higher levels of Se were detected among diabetics with poor glycemic control. Data regarding serum levels of Se among patients with T2DM are inconsistent however low serum level of Se among patients with T2DM has been reported..$^{29}$ Similarly low levels of Se have also been reported in women with gestational diabetes mellitus. ${ }^{30}$ Se is an anti-oxidant and provides protection against oxidative stress ${ }^{31}$ that has been implicated in the etiology, pathogenesis and complications of T2DM. ${ }^{32}$ Deficiency of Se may therefore be a predisposition for development of diabetes. On the contrary long-term supplementation of Se has been linked with increased likelihood of development of T2DM. ${ }^{33}$ This was evident in the present study where the group of patients with poor glycemic control had high blood levels of Se. The exact role of Se in the pathogenesis of T2DM remains elusive emphasizing the need for further investigations to gain a better insight regarding Se metabolism in T2DM.

\section{Conclusion}

serum $\mathrm{Cu}, \mathrm{Zn}$ and Se levels were altered among patients with T2DM compared to the normal healthy controls. Glycemic control among T2DM was observed to influence the blood levels of trace elements where poor glycemic control was associated with significant elevation of $\mathrm{Cu}, \mathrm{Zn}$ and Se. This study was however limited by small numbers and large-scale studies are recommended to validate the findings of the present study in order to gain a better understanding of trace element homeostasis in T2DM.

\section{Acknowledgements}

The author would like to thank Ms. Evelyn Garcia 
Donguines for technical assistance and Prof. Zahid Shakoor for his thought-provoking discussions.

\section{Conflict of interest}

None declared.

\section{References}

1. S P, Pasula S, Sameera K. Trace elements in diabetes mellitus. J Clin Diagn Res. 2013; 7(9):1863-5.

2. Fraga CG. Relevance, essentiality and toxicity of trace elements in human health. Mol Aspects Med. 2005;26(45):235-44.

3. Ekmekcioglu C, Prohaska C, Pomazal K, Steffan I, Schernthaner G, Marktl W. Concentrations of seven trace elements in different hematological matrices in patients with type 2 diabetes as compared to healthy controls. Biol Trace Elem Res. 2001;79(3):205-19.

4. Chen YW, Yang CY, Huang CF, Hung DZ, Leung YM, Liu SH. Heavy metals, islet function and diabetes development. Islets. 2009;1(3):169-76. doi: 10.4161/isl.1.3.9262.

5. Kowluru RA, Kennedy A. Therapeutic potential of anti-oxidants and diabetic retinopathy. Expert Opin Investig Drugs. 2001;10(9):1665-76.

6. Valko M, Morris H, Cronin MT: Metals, toxicity and oxidative stress. Curr Med Chem. 2005;12(10):1161-1208.

7. Chausmer AB. Zinc, insulin and diabetes. J Am College Nutr. 1998;17:109-14 PubMed

8. Chistiakov DA, Voronova NV. Zn (2+)-transporter-8: a dual role in diabetes. Biofactors. 2009; 35(4): 356 PubMed -63. doi: 10.1002/biof.49.

9. Bandeira VDS, Pires LV, Hashimoto LL, Alencar LL, Almondes KGS, Lottenberg SA, et al. Association of reduced zinc status with poor glycemic control in individuals with type 2 diabetes mellitus. J Trace Elem Med Biol. 2017;44:132-136. doi: 10.1016/j.jtemb.2017.07.004. PubMed Epub 2017 Jul 12.

10. Bo S, Durazzo M, Gambino R, Berutti C, Milanesio $\mathrm{N}$, Caropreso A, et al. Associations of dietary and serum copper with inflammation, oxidative stress, and metabolic variables in adults. J Nutr. 2008;138(2):305 PubMed -10. 11. Park K, Gross M, Lee DH, Holvoet P, Himes JH, Shikany JM, et al. Oxidative stress and insulin resistance: the coronary artery risk development in young adults study. Diabetes Care. 2009;32(7):1302 PubMed -7.

12. Car N, Car A, Granić M, Skrabalo Z, Momcilović B. Zinc and copper in the serum of diabetic patients. Biol Trace Elem Res. 1992 Jan-Mar;32:325-9.

13. Al-Maroof RA, Al-Sharbatti SS. Serum zinc levels in diabetic patients and effect of zinc supplementation on glycemic control of type 2 diabetics. Saudi Med J. 2006 Mar;27(3):344-50.

14. Rajpathak S, Rimm E, Morris JS, Hu F. Toenail selenium and cardiovascular disease in men with diabetes. $J A m$ Coll Nutr. 2005;24:250-6 PubMed .

15. Laclaustra M, Navas-Acien A, Stranges S, Ordovas JM, Guallar E. Serum selenium concentrations and diabetes in U.S. adults: National Health and Nutrition Examination Survey (NHANES) 2003-2004. Environ Health Perspect. 2009;117:1409-13.

16. Ferdousi S, Mollah FH, Mia MAR. Serum levels of zinc and magnesium in newly diagnosed type-2 diabetic subjects. Bangladesh J Med Biochem. 2010;3:46-9.

17. Lau AL, Failla ML. Urinary excretion of zinc, copper and iron in the streptozotocin-diabetic rat. $J$ Nutr. 1984;114(1):224 PubMed -33.

18. Soinio M, Marniemi J, Laakso M, Pyorala K, Lehto $\mathrm{S}$, Ronnemaa T. Serum zinc level and coronary heart disease events in patients with type 2 diabetes. Diabetes Care. 2007;30(3):523 PubMed -8. doi: 10.2337/dc06- 1682.

19. Chasapis CT, Loutsidou AC, Spiliopoulou CA, Stefanidou ME. Zinc and human health: an update. Arch Toxicol. 2012;86(4):521 PubMed -34. doi:10.1007/ s00204-011-0775-1

20. Jayawardena R, Ranasinghe P, Galappatthy P, Malkanthi RLDK, Constantine GR, Katulanda P. Effects of zinc supplementation on diabetes mellitus: a systematic review and meta-analysis, Diabetol. Metab. Syndr. 4(2012) 1.

21. Beshgetoor D, Hambidge M. Clinical conditions altering copper metabolism in humans. Am J Clin Nutr. 1998;67(5 PubMed Suppl):1017S-21S.

22. Abou-Seif MA, Youssef AA. Evaluation of some biochemical changes in diabetic patients. Clin Chim Acta. 2004;346(2):161 PubMed-70. doi: 10.1016/j. cccn.2004.03.030.

23. Masad A, Hayes L, Tabner BJ, Turnbull S, Cooper LJ, Fullwood NJ et al. Copper-mediated formation of hydrogen peroxide from the amylin peptide: a novel mechanism for degeneration of islet cells in type-2 diabetes mellitus? FEBS Lett. 2007;581(18):3489 PubMed -93. Epub 2007 Jul 2.

24. Prasad AS. Clinical, immunological, anti-inflammatory and antioxidant roles of zinc. Exp Gerontol. 2008;43(5):370 PubMed -7. Epub 2007 Nov

25. Sarkar A, Dash S, Barik BK, Muttigi MS, Kedage V, Shetty JK, et al. Copper and ceruloplasmin levels in relation to total thiols and GST in type 2diabetes mellitus 
patients. Indian J. Clin. Biochem. 2010;25:74-76 PubMed. 26. Eaton JW, Qian M. Interactions of copper with glycated proteins: possible involvement in the etiology of diabetic neuropathy. Mol Cell Biochem. 2002;234-235(1 PubMed -2):135-42.

27. Hamasaki H, Kawashima Y, Yanai H. Serum Zn/Cu Ratio Is Associated with Renal Function, Glycemic Control, and Metabolic Parameters in Japanese Patients with and without Type 2 Diabetes: A Cross-sectional Study. Front Endocrinol (Lausanne). 2016;7:147. eCollection 2016. 28. Atari-Hajipirloo S, Valizadeh N, Khadem-Ansari MH, Rasmi Y, Kheradmand F. Altered Concentrations of Copper, Zinc, and Iron are Associated With Increased Levels of Glycated Hemoglobin in Patients With Type 2 Diabetes Mellitus and Their First-Degree Relatives. Int J Endocrinol Metab. 2016;14(2):e33273. eCollection 2016. 29. Durak R, Gülen Y, Kurudirek M, Kacal M, Capogron- lu I. "Determination of trace element levels in human blood serum from patients with type II diabetes using WDXRF technique: a comparative study. Journal of X-Ray Science and Technology. 2010;18(2):111-120.

30. Kong FJ, Ma LL, Chen SP, Li G, Zhou JQ. Serum selenium level and gestational diabetes mellitus: a systematic review and meta-analysis. Nutr J. 2016;15(1):94.

31. Burk RF. Selenium, an antioxidant nutrient. Nutr Clin Care. 2002;5(2):75-9

32. Robertson RP, Harmon JS. Pancreatic islet beta-cell and oxidative stress: the importance of glutathione peroxidase. Febs Lett. 2007;581(19):3743-8

33. Stranges S, Marshall JR, Natarajan R, Donahue RP, Trevisan M, Combs GF, et al. Effects of long-term selenium supplementation on the incidence of type 2 diabetes: a randomized trial. Ann Intern Med. 2007;147:217-23 PubMed . 